\title{
Ethics - dental registration in the seventeenth and early eighteenth century
}

\author{
M. Bishop, ${ }^{1,2}$ S. Gelbier, ${ }^{3}$ and D. Gibbons, ${ }^{4}$
}

\begin{abstract}
In the histories of dentistry, some mention is made of the licensing of tooth-drawers, and those who provided dental healthcare before the term Dentist started to become general in the late eighteenth and early nineteenth centuries. One of the most striking references to licensing appears in a little piece of doggerel printed under a 1768 print by Dixon after Harris.
\end{abstract}

7 he scene is a smithy, and the blacksmith 1 is acting as tooth-drawer to an old lady while her husband looks on;

'Why squeeze your Hat, and seize my Cap As if you dreaded some Mishap.

Prove not your Spirits on the Rack

See a Licentiate Not a Quack'

The print itself was used to illustrate a chapter in The Roots of Dentistry edited by Christine Hillam in 1990 for the British Dental Association, and the introduction to the chapter makes it clear that some of those who treated teeth and toothache were licensed by the Company of Barber Surgeons of London, or by their local bishop. ${ }^{1}$

\section{Background}

Recent discoveries in the archives of Lambeth Palace Library relating to medical licensing by the Vicar General of the Archbishop of Canterbury a century earlier than the doggerel, have come as a useful addition to the historical record, showing practitioners of the dental arts registering under the same exacting terms as their medical colleagues, at a time when the Church was the major licensing authority for medicine and surgery outside London.

$\overline{1^{*} \text { GDP, Past President BSDMFR, Queen Anne House, }}$ $2 a$ St Andrew St, Hertford, Hertfordshire SG14 1JA; ${ }^{2}$ PhD Student ${ }^{3}$ Professor of Dental Public Health, Head of Division, Division of Dental Public Health, Oral Health Services Research and The Schools of Dental Nursing, Guy's King's and St Thomas' Dental Institute, King's Denmark Hill Campus, Caldecot Rd, Denmark Hill, London SE5 9RW; ${ }^{4}$ Professor, Division of Dental Public Health, Oral Health Services Research and The Schools of Dental Nursing,

Guy's King's and St Thomas' Dental Institute, Guy's Campus.

${ }^{*}$ Correspondence to: Malcolm Bishop

REFEREED PAPER

Received 20.03.01; Accepted 02.07.01

(c) British Dental Journal 2001; 191: 395-400
The Archbishop of Canterbury could, and still can, award degrees, and he and the other Bishops could award medical licences, although the practice had fallen into abeyance some hundred years previ-

In brief

- Shows benefit of ecclesiastical records in dental history

- Clarifies status of dental practitioners in the late seventeenth and early eighteenth century

- Gives insight into provision of dental healthcare in the provinces

- Shows activity (official) of women in medical and dental healthcare

- Reveals official requirement for continued compliance for retaining licences in the late seventeenth and early eighteenth century

ous to the passing of the Medical Acts of $1858,{ }^{2}$ which set up The General Council of Medical Education and Registration of the United Kingdom.

Detailed work on the registration functions in Medicine which were part of the normal business of the Church was taken in hand by A. W. J. Haggis, who from 1937 until his untimely death in 1946, worked in the Wellcome Library. This work has not been published, and Haggis was unaware of all of the Lambeth Data. Others who preceded and followed him, ${ }^{3}$ have their important contributions acknowledged in the introductory essay and selected reading list appended to the Directory of Medical Licences at Lambeth. ${ }^{4}$

As Haggis showed, and the Lambeth papers confirm, the Church's medical registrations by far outnumbered those of the Royal Colleges and Universities.

The first licences following the Henrician statute of 1511, were those issued by the vicar general on behalf of the Archbishop of Canterbury, and were limited to the province of Canterbury. However, none is recorded in Lambeth Palace Library until Archbishop Grindal's register in 1576.

After the Peter's Pence Act of $1533,{ }^{5}$ the Archbishop, through his Master of the Faculties, issued dispensations throughout all England. Applicants were expected to provide evidence of their medical or surgical expertise, such as letters testimonial. Where the candidate was recommended by local clergy, physicians, or parishioners, or a mixture of these, the Faculty Office insisted on the countersigning or examination by two fellows of the College of Physicians. ${ }^{6}$

The relevant Act of Henry VIII earlier mentioned, which was brought into being by the renaissance genius of Cardinal Wolsey and the physician Thomas Linacre, and on the requirements of which the Church insisted, is clear: ${ }^{7}$

'.... [that] no Person out of the said City, and Precinct of Seven Miles of the same, except he have been (as is aforesaid) approved in the same, take upon him to exercise and occupy as a Physician or Surgeon, in any Diocese within this Realm, but if he be first examined and approved by the Bishop of the same Diocese, or, he being out of the Diocese, by his Vicar General; either of them calling to them such expert Persons in the said Faculties, as their Discretion shall think convenient, and giving their Letters Testimonials under their Seal to him that they shall so approve, upon like Pain lof Forfeiture for every Month that they do occupy as Physicians or Surgeons, not admitted nor examined after the Tenour of this Act, of v.li. [ 55$]$ to be imployed the one Half thereof to the Use of our Sovereign Lord the King, and the other Half thereof to any Person that will sue for it by Action of Debt, in which no wager of Law nor Protection shall be allowed.] to them that occupy the contrary to this Act (as is above said) to be levied and imployed after the Form before expressed.' 


\section{The Lambeth Project}

In 2000, a project looking into these medical licences, funded by the Wellcome Trust, and carried out by Miss Melanie Barber, the deputy Librarian and Archivist of the Library in Lambeth Palace, was completed with the issue of the Directory of Medical Licences Issued by the Archbishop of Canterbury 1536-1775 Part 2: Faculty Office Series $2000 .^{8}$

This list of 123 doctors licensed by the Faculty Office between 1536 and 1775, joins the previously completed list of 947 names of Physicians and Surgeons in the 'Directory of Medical Licences Issued by the Archbishop of Canterbury 1536-1775 Part 1: Vicar General Series 1997.9

In the longer Vicar General list are the names of four men and one woman skilled in dentistry. Two of the men, John Anthony, and Peter Hemet, are described as purely practising on the teeth, and from the entry for Peter Hemet it can be seen that the status and function of the tooth-drawer can fairly be associated with the later term dentist, for his fiat states that he may 'practise $y^{e}$ branch of chirurgery of Tooth drawer and all the operations belong to the same part', and his signatories are three surgeons, one of whom, Stephen Ronjat, having been the late King's Serjeant Surgeon. The documentary evi- dence for Elizabeth Moore, a medical practitioner, highlights her skills in the treatment of toothache.

The documents at Lambeth show that the Archbishop of Canterbury's Vicars General licensed 12 female medical practitioners, of whom Elizabeth Moore was the second last, and was the only one to be singled out for her dental and oral medicine skills. The last woman licensed was Mary Rose in 1696.

Three of the 'dentists' were licensed in Latin before 1625, then Mrs Moore's documents are in English in 1689, and so are those of the last, Peter Hemet, who was licensed in 1702. The earlier Latin entries are significant from the medical ethics standpoint, as they adhere to a formal convention, and make it quite clear, for example in these extracts translated from William Lee's entry (Fig. 1), that the candidate must first be qualified (as with most of the Church registrations, the qualification was empirical), 'Whereas according to the appeal worthy of faith of many we have heard you for several years happily have been versed in the art of curing and ?easing? toothache, and expertly extracting incurable teeth (if perchance they are so) ... and that you have cured several who despaired of recovering their health (with God as your helper) and have restored them to their for- mer strength' and second must also maintain standards to continue to be 'registered'. 'we grant and bestow to you our licence and faculty in this matter by the tenor of [letters] patent as long as you conduct yourself well and praiseworthily.' In this the requirements for registration and continued registration 400 years ago look much the same as those of today. Important points lie also in the incidental detail, for example, as can be seen above, conservation of teeth was counted as more important than extraction.

As well as providing an invaluable guide to the tasks expected of the tooth-drawer, as seen earlier, the later, post civil war, English documents are interesting for their revelation of the range of cures claimed. The front page of that of Mrs Moore is illustrated (Fig. 2). Although she cannot be claimed as the first woman dentist, as it is only as part of her skill that dentistry features, it is reasonable to see in her both the enlightenment of the Church that registered her, and the place of dentistry in such a general medical practitioner's life, since Mrs Moore's remedies for dental ills could have been medical or surgical, for the four signatories to her testimonial declare her to be 'of good skill in Physic and Chirurgery, and very fit (in our opinion) to practise them?

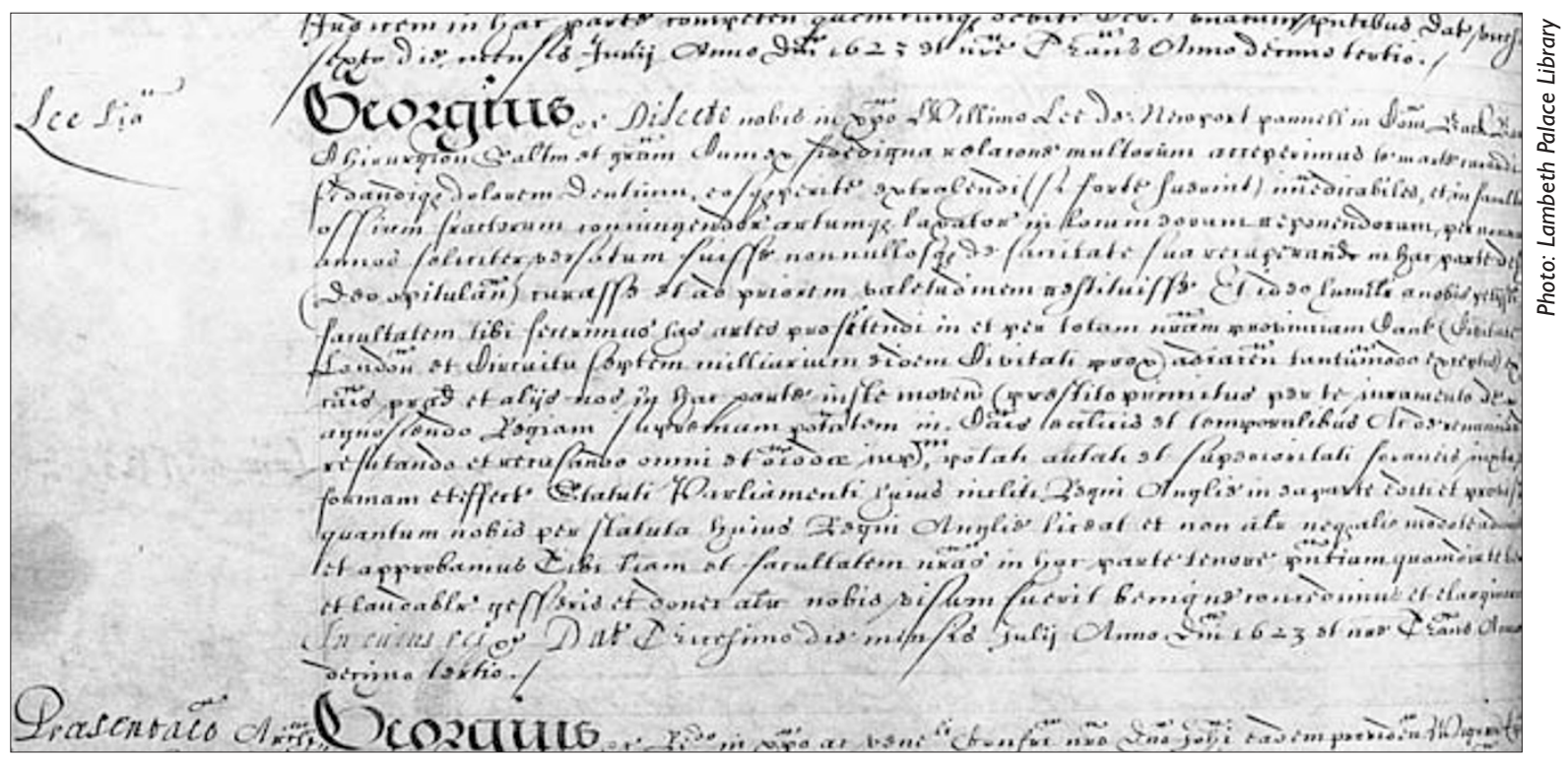

Fig. I The entry for William Lee. 30th July I623 Abbot 2, f.203v 


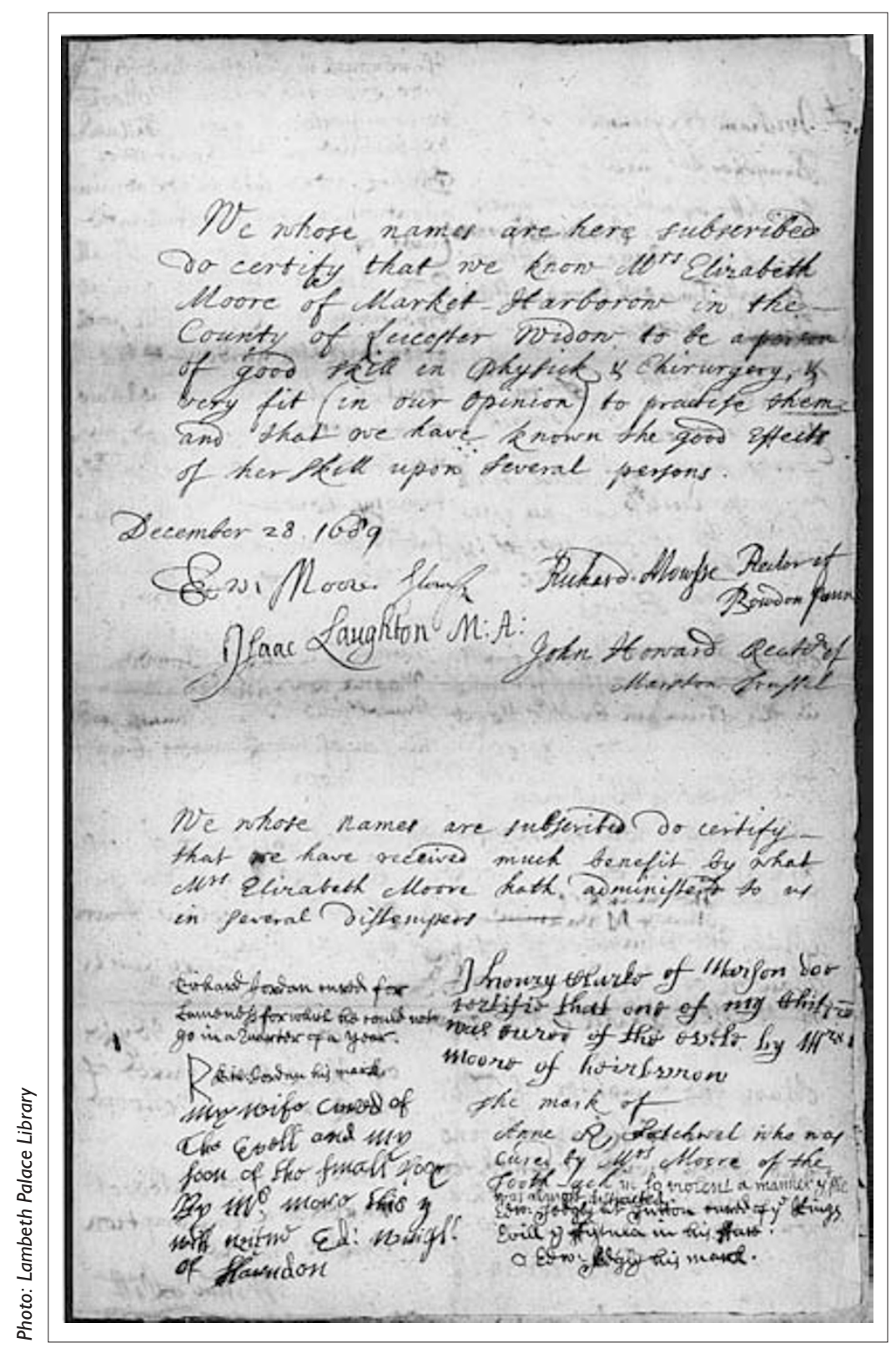

\section{Women in practice}

That women were in practice as toothdrawers 60 years later is known, Lilian Lindsay in A Short History of Dentistry draws atten-tion to Fielding's account in 1754 of a 'female of great eminence in the art' in Wapping, ${ }^{10}$ so this earlier inclusion of a specific mention of dental expertise in a woman in the Lambeth records is an important backward extension of the historical record.

It can also be claimed that women extracted teeth in the fifteenth and sixteenth centuries, as evidenced by implication in the secular entry of Isabell Warwicke to the Gild of Barber Surgeons of York in 1572 as a surgeon, for as R. A. Cohen in his authoritative introduction ${ }^{11}$ to the 1969 facsimile edition of Charles Allen's 1685 book The Operator for the Teeth points out, the regulations of the Gild (sic) ${ }^{12}$ specifically mention 'dentium extractione' as a function of surgery, and men or women who practised without training were to be fined.

The licensing of these 'dentists' and female practitioners suggests perhaps an enlightened Archbishop or Vicar General. Of the dental entries three are under George Abbot, Archbishop 1610-1633, and Sir Thomas Ridley, Vicar General 1611-1628 and two under two Archbishops but one Vicar General (William Sancroft, Archbishop 1678-1689, Thomas Tenison, Archbishop 1695-1715,George Oxenden, Vicar General 1688-1703) This suggests that the Vicar General wielded the influence, but further evidence would be needed to make this assertion with any confidence. It certainly points to a rapid development in the hundred years since the flurry of Henrician Acts relating to medicine, and it can be regretted that the pace was not maintained. However it started, the development for
Fig. 2 The front page of Mrs. Elizabeth Moore's letters testimonial. 28th December, I 689 VX IA/10/259

women and for 'dentists' can be seen as a bold move in the context of the initially discouraging words of the 1511 Act:

¿...common Artificers, as Smiths, Weavers, and Women [probably 'wise-women'], boldly and accustomably take upon them great Cures, and Things of great Difficulty, in the which they partly use Sorcery and Witchcraft, partly apply such Medicines unto the Disease as be very noious, and nothing meet therefore, to the high Displeasure of God, great Infamy to the Faculty, and the grievous Hurt, Damage, and Destruction of many of the King's liege people, most especially of them that cannot discern the uncunning from the cunning.'

It is to the class of 'Artificers' that the toothdrawers may have been considered to have belonged until the twentieth century. It is no discredit to be an artisan, the problem lay with going beyond their capabilities.

As well as evidence of their 'cunning' or knowledge, and suitability, an oath or affirmation was required of candidates. After the reformation this Oath required both agreement to selected items of the 39 articles and loyalty to the Crown.

By kind permission, Lambeth Palace Library has allowed the publication of the entries relating to the four seventeenth century, and one early eighteenth century, dentists.

The numbers preceding the names are the numbers of the entries in the Directory, which also provide location by town and county, along with full notes and two introductory essays. The lists are available to scholars via the internet, address: www.lambethpalacelibrary.org

\section{The Lambeth Directory entries}

The George who is mentioned is the Archbishop, George Abbot.

895. WHITEING (WHITINGE) (Edward) of St. Margaret, Ipswich, Suffolk.

10 March 1622: Abbot 2, f.201v. (Fig. 3)

'Georgius etc Dilecto nobis in christo Edwardo Whiting...'

'George etc to our Beloved in Christ Edward Whiting of the parish of St Margaret in the town of Ipswich of the diocese of Norwich and 


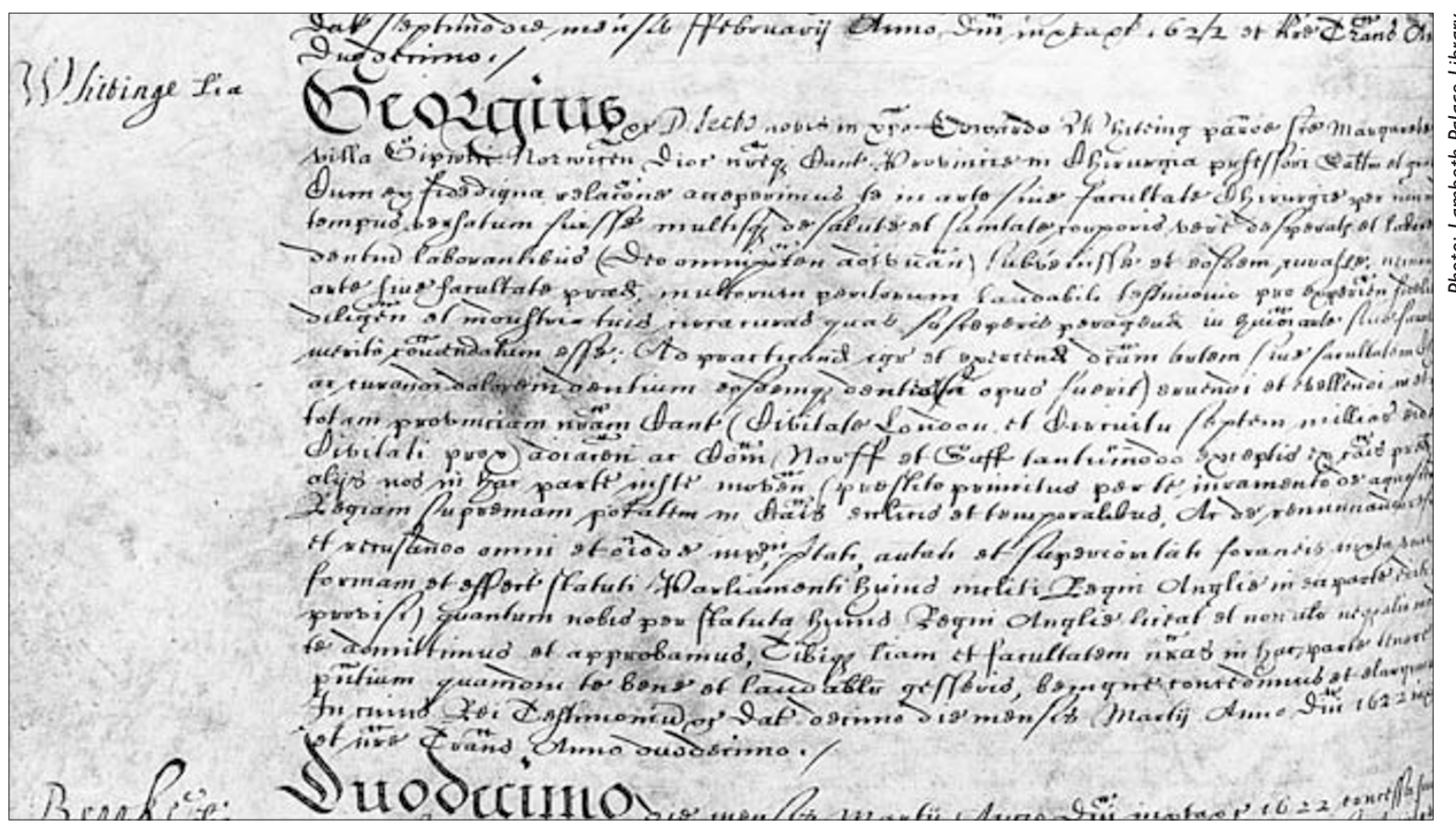

Fig. 3 The entry for Edward Whiting(e). I0th March 1622. Abbot 2, f.20 Iv

of this province of Canterbury, doctor in surgery, greeting and grace. Whereas according to the appeal worthy of faith we have heard you have been versed with the art of surgery without a faculty for not a little time and have turned many who were despairing of the safety and health of their body and have assisted those inflicted with toothache (with the help of almighty God) and have cured them, and yet with the art without a faculty aforesaid, the cures which you have undertaken carrying through in this skill without a faculty have justly been commended by the praiseworthy testimony of many experts for your experience, faith, diligence and active care. Therefore for the practising and exercising of the aforesaid skill without a faculty of surgery and of curing toothache and of saving and removing the same teeth (as need arises) in and through the whole of our province of Canterbury (the City of London and a circuit of seven miles lying adjacent to that city etc. and the counties of Norfolk and Suffolk only excepted) from the aforesaid causes and others we undertake immediately in this matter (as previously you have sworn an oath of acknowledgement of the supreme power of the King in matters spiritual and temporal and of the recollection refutation and rejection of every and all kinds of impieties, [the King's] authority and superiority being superior to others according to the force decision and effect of the Statute of Parliament of this famous kingdom of England put forth and foreseen in this matter) as much as we are allowed by the statutes of this Kingdom of England and not otherwise nor in another way do we admit and approve you and freely we grant and bestow to you our licence and faculty in this matter by the tenor of [letters] patent as long as you conduct yourself well and praiseworthily. In witness whereof etc. Given on the 10th day of the month of March in the year of our Lord 1622 etc. and in the 12 th year of our translation.

498 LEE (William) barber-surgeon, of Newport Pagnell, Bucks.

30 July 1623: Abbot 2, f.203v. (Fig. 1)

'George to our Beloved in Christ William Lee of Newport Pagnell in the county of Buckingham, Barber Surgeon, greeting and grace. Whereas according to the appeal worthy of faith of many we have heard you for several years happily have been versed in the art of curing and ?easing? [Trans uncertain] toothache, and expertly extracting incurable teeth (ifperchance they are so), and in the way of setting broken bones and of replacing dislocated joints in their place, and that you have cured several who despaired of recovering their health (with God as your helper) and have restored them to their former strength, and moreover humbly you have sought from us that we should grant you a faculty of practising these arts in and through our whole province of Canterbury (the City of London

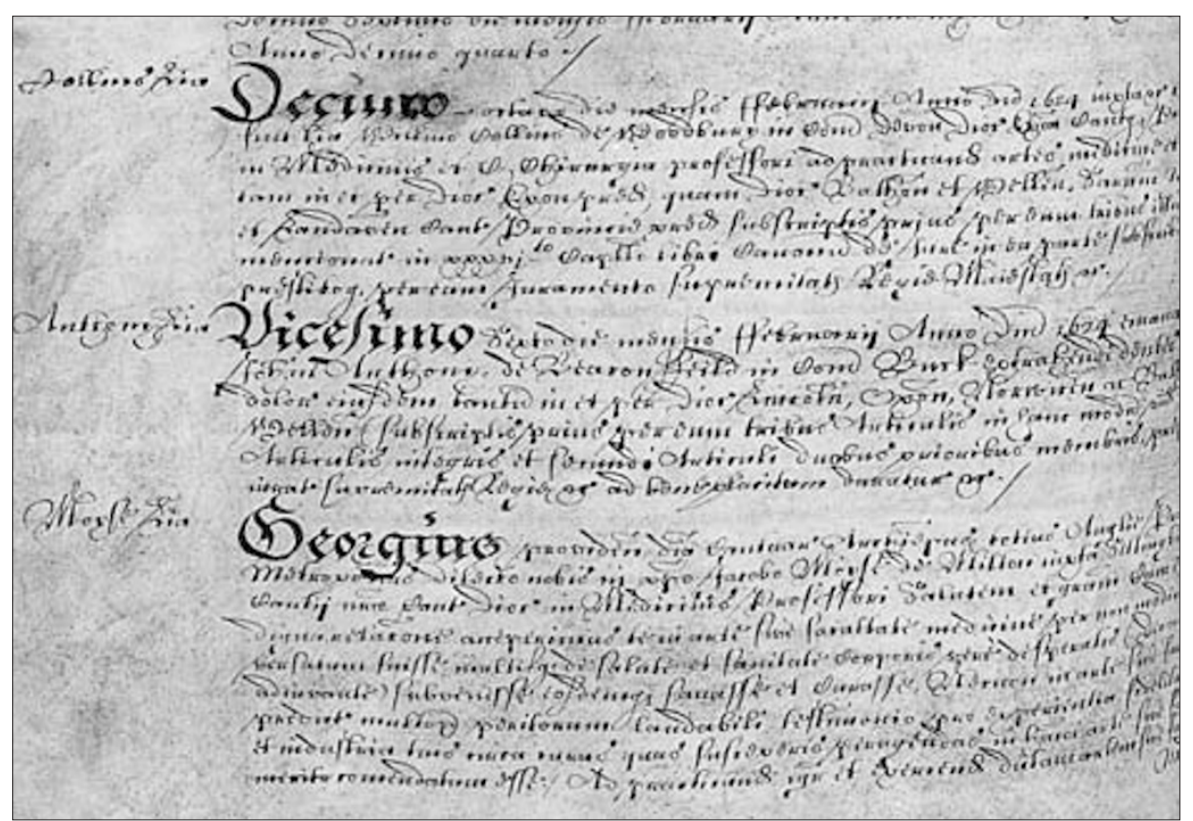

Fig. 4 The entry for John Anthony. 26th Feb I 624 Abbot 2, f.208 v with other entries on unrelated matters 


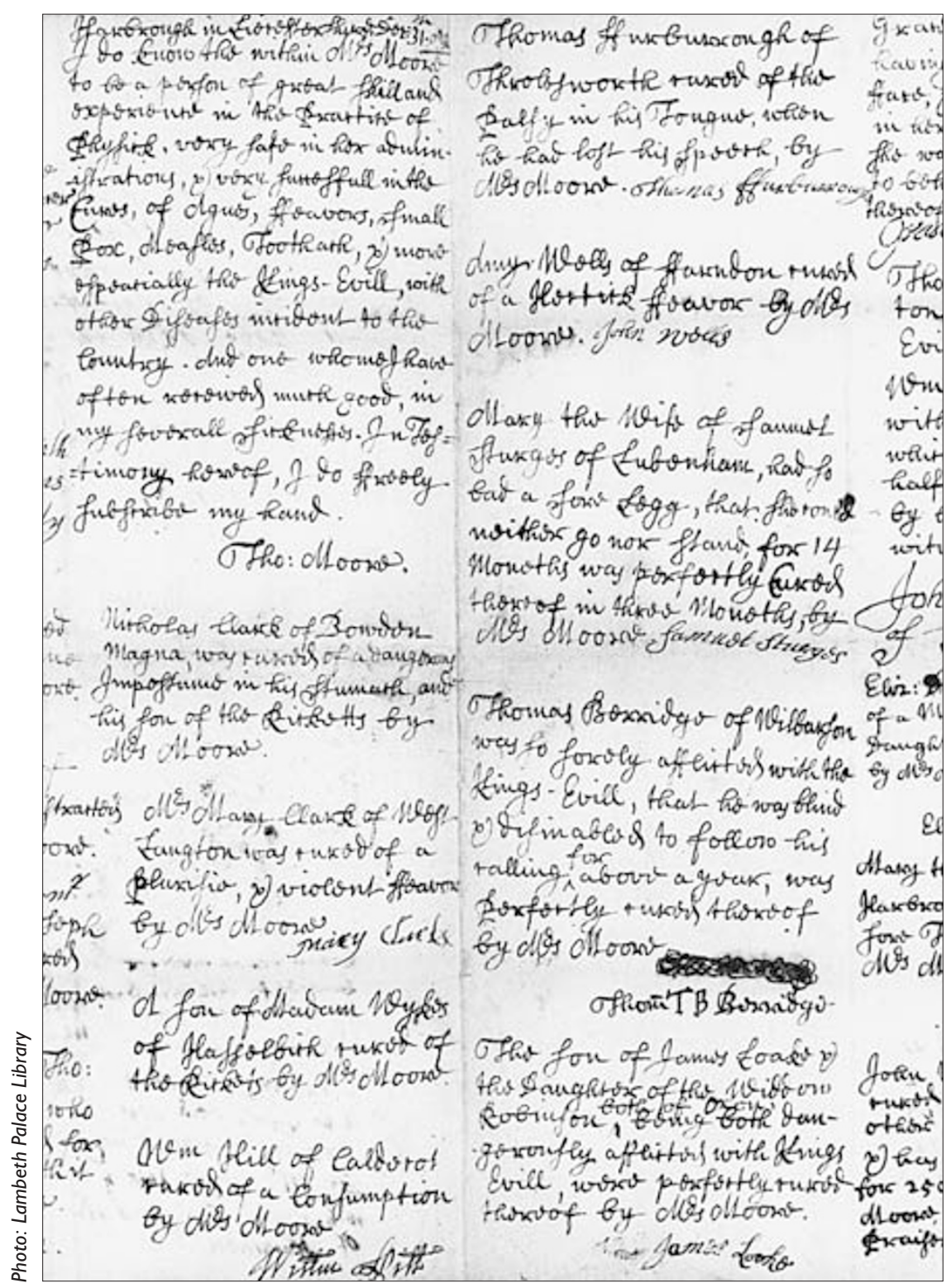

and a circuit of seven miles lying adjacent to that city being the sole exceptions) from the aforesaid causes and others we undertake immediately in this matter (as previously you have sworn an oath acknowledging the Royal Supremacy in matters spiritual and temporal and of recollection refutation and rejection of every and all kinds of impieties, [the King's] authority and superiority being superior to others according to the force decision and effect of the Statute of Parliament of this famous kingdom of England put forth and foreseen in this matter] as much as we are allowed to by the statutes of this kingdom of England and not otherwise nor in another way do we admit and approve you and we freely grant and bestow to you our licence and faculty in this matter by the tenor of [letters] patent as long as you conduct yourself well and praiseworthily and until it seems otherwise to us. In [witness] whereof etc. Given on the 30th day of the month of July in the year of our Lord 1623 and the 13th year of our translation.'

\section{ANTHONY (John), of Beaconsfield} Bucks.

26th Feb 1624: Abbot 2, f.208v. (Fig. 4)

'Vicesimo sexto die mensis Februarii Anno Domini 1624 ...

'On the 26th day of the month of February in the year of our Lord 1624 [the Archbishop] issued a licence to John Anthony of Beaconsfield in the county of Buckingham to extract teeth and relieve toothache only in and throughout the dioceses of Lincoln, Oxford, Norwich, and Bath and Wells (previously he had subscribed to three Articles in this way namely the third Article whole and the first two parts of the second Article, and making an oath he swore to the Royal supremacy etc. [the licence] will last [as long as is pleasing] etc.'

563 MOORE (Elizabeth), widow, of Market Harborough, Leics. 1689 (Fig. 2,5)

Letters testimonial signed by Edward Moore, Isaac Laughton, M.A., Richard Mousse, rector of Bowden Parva, Leics.,
Fig. 5 Some of the testimonials for Mrs. Elizabeth Moore

and John Howard, rector of Marston Trussell, Northants., 28 Dec. 1689, annotated with the fiat of Thomas Pinfold, surrogate, 9 Jan 1690. The document includes certificates of patient's cures from the following illnesses: 'Anne R Satchwel, who was cured of the toothach' [there is above this added in another hand and stating how bad the toothache was 'in so violent a manner $y^{t}$ she was almost distracted']; Thomas Huxborough of Throlsworth, cured of the palsy in his tongue, when he had lost his speech; and Mary, the wife of John Pike of Flaxborough was cured of a dangerous sore throat in her lying in. Thomas Moore certified that she is 'a person of great skill and experience in the practice of physick, very safe in her administrations, \& very successfull in the cures of agues, feavers, small pox, measles, toothach \& more espeacially the king's-evill, with other diseases incident to the country, and one [from] whome I have often received much good in my severall sicknesses'. Another had made use of 'no other physician for 25 or 26 years, but the said Mrs Moore \& with good success'.

Licensed to practise medicine and surgery in the dioceses of Coventry and Lichfield, Lincoln and Peterborough, 17 Jan. 1690: Dean and Chapter register f.32. VX $1 \mathrm{~A} / 10 / 259$

401 HEMET alias HORNET (Peter) of St Clement Danes. Middx. 1702

Transcription from the archive document. (a fiat) (Fig. 6)

'These are to Certifie all whom it may Concerne That Mr peter hemet of St. Clemen's Danes in the County of Midlesex is very fittly qualified to practise ye branch of chirurgery of Tooth drawer and all the operations belong to the same part, wittnesse my hand $y^{e} 29^{\text {th }}$ day of September 1702.'

Stephen Ronjat, his latte Majestys's Sergeant Surgeon, and Fr. Maynial, surgeon, annotated with the fiat of William Clements, surrogate, 29 Sept. 1702; another of same date signed by $\mathrm{P}$ [eter] Ruleau, [surgeon], and Fr. Maynial, surgeon: VX 1A/10/355/1-2.

Subscription, 29 Sept. 1702: VG 1/6, f. $182 \mathrm{v}$. 


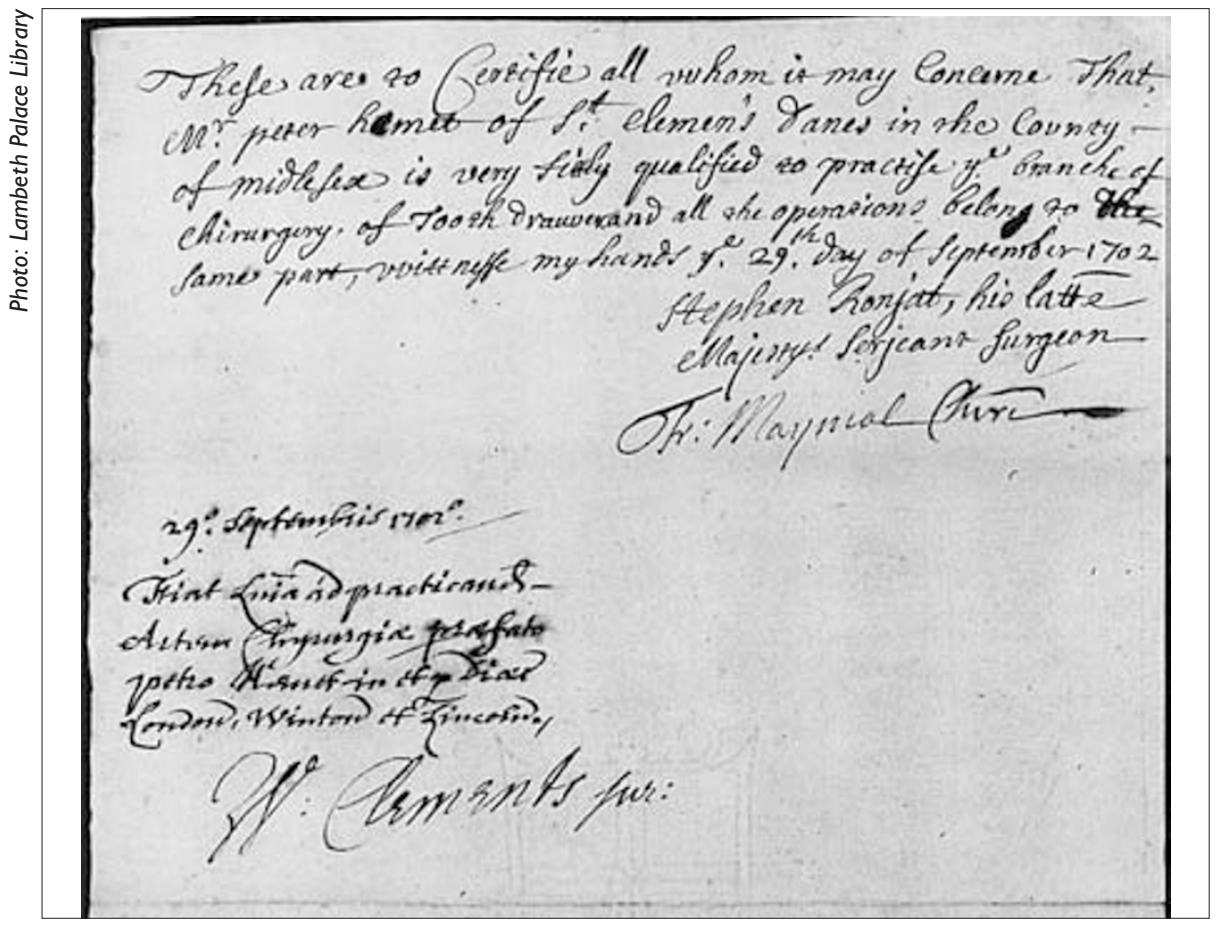

Fig. 6 The Fiat for Peter Hemet 29th September, I702. IA// 0/355/I-2

Licensed to practise surgery in the diocese of Lincoln, London and Winchester, 29 Sept. 1702: Tenison 1, f.136.

\section{Conclusion}

Although it seems for lack of evidence to the contrary that this flurry of licenses was a false dawn in the ethico-legal development of the profession, the system of training, examination, initial licensing, and continuing registration required of the few who are recorded, bears so close a resemblance to that of today that it does not seem in the least quaint, and casts a new light on the other surviving evidence. These were serious people going about the serious business of delivering dental healthcare as best they were able within the knowledge of the day.

The seventeenth century was a time of astonishing advance in scientific medicine and surgery, well described by Lilian Lindsay in her A Short History of Dentistry already mentioned. William Harvey had published his findings on the circulation of the blood in 1628, Malpighi identified the capillaries in 1666, and in dentistry the Microscopist Anton van Leeuwenhoek identified the dentinal tubules and bacteria in the materia alba. Since he submitted 375 papers to the Royal Society, his work was freely available in England. The earliest surviving English treatise on dentistry, Charles Allen's The Operator for the Teeth, ${ }^{13}$ was published in York in 1685 and Dublin in 1686, and was sold in London from 1687. Dentistry, an Illustrated History, published in 1985 by Malvin Ring ${ }^{14}$ provides the illustrations the Lindsay book lacks, showing what superb anatomical illustrations of the head and teeth were available to the practitioners of the day who chose to base their profession on scientific knowledge.

Comparable hard evidence of the development of the ethico-legal basis of dentistry in the seventeenth century is sparse, and this unsuspected new information is most welcome. That it has come to light now is thanks entirely to the eagle eye and meticulous classification of Miss Melanie Barber,
Archivist at Lambeth Palace Library, whom the authors would additionally like to acknowledge for her assistance in preparing this paper. Acknowledgement is also gratefully given to Mrs. Sarah Wickham ${ }^{\dagger}$ for transcribing and translating the Latin. The translation is deliberately literal.

\section{${ }^{*}$ Melanie Barber is the Deputy Librarian and} Archivist at Lambeth Palace Library, London SE1 7JU + Sarah Wickham is the Assistant Archivist at Lambeth Palace Library, London SE1 7JU

All illustrations are by permission of Lambeth Palace Library

1 Hillam C (ed). The Roots of Dentistry. The Lindsay Society. London: British Dental Association, 1990 pp35/6.

2 The Medical Act $21 \& 22$ Vict. Cap. 90, 2nd August 1858.

3 eg Raach J. H. A Directory of English country physicians, 1603-1643 (1962);

Bloom J H, James R R. Medical practitioners licensed under the Act of 3. Henry VIII in the diocese of London (1935); and Peters V, Assistant Archivist in Lambeth Palace Library. Alphabetical list of medical practitioners. (1990).

4 Barber M. Directory of Medical Licences Issued by the Archbishop of Canterbury 1536-1775 part 2: Faculty Office Series. Lambeth Palace Library, 2000 p.xv

5 Statutes at Large. A.D. 1533. Anno vicesimo quinto HENRICI VIII CAP.XXI

6 Barber M. Directory of Medical Licences Issued by the Archbishop of Canterbury. 1536-1775 part 2: Faculty Office Series. Lambeth Palace Library, 2000 p.viii

7 Statutes at Large. A.D. 1511. Anno tertio HENRICI VIII. CAP.XI. P.113

8 Barber M. Directory of Medical Licences Issued by the Archbishop of Canterbury. 1536-1775 Part 2: Faculty Office Series. Lambeth Palace Library, 2000

9 Barber M. Directory of Medical Licences Issued by the Archbishop of Canterbury 1536-1775. Part 1: Vicar General Series, Lambeth Palace Library, 1997.

10 Lindsay L. A Short History of Dentistry. London: John Bale, Sons and Danielsson, Ltd., 1933, p49.

11 Cohen R A. Introduction to Charles Allen's 'The Operator for the Teeth' 1685. London 1969. Dawson's of Pall Mall. p.iii.

12 Sellers M (ed). The York Memorandum Book Part I (1376-1419) 1912. The Surtees Soc. CXXX.

13 Allen C. The Operator for the Teeth. York 1685 Dublin 1686 (limited edn. of 250 copies reprinted by Dawson's of Pall Mall, 1969)

14 Ring M E. Dentistry, An Illustrated History. New York: Harry N. Abrams Inc, Publishers. St. Louis, Toronto: The C.V. Mosby Company, Princeton. 1985 pp144-156. 